\title{
Managing Contention: Divergent Government Responses to Youth Protests in the Arab World
}

\author{
Kressen Thyen \\ Eberhard Karls Universität Tübingen / GIGA (German Institute of Global \\ and Area Studies) \\ kressen.thyen@uni-tuebingen.de; kressen.thyen@giga-hamburg.de
}

\begin{abstract}
Why do some authoritarian governments respond beneficently to political protest while others opt for repression? This article argues that beneficent government responses in the form of concessions or institutional inclusion are fostered by three interrelated mechanisms working at three distinct levels: institutionalization of political protest within the polity, external certification of protest demands by legally legitimized authorities, and interest polarization between protesting groups and the government. Empirical comparison of government responses to youth protests before and during the 2011 uprisings in Morocco and Egypt proves that the divergent strategies in the two countries were not the result of spontaneous decision-making in times of heightened regime contention. Rather, they mirror established patterns of protest politics that are relatively resistant to ad-hoc manipulations. By extending the focus beyond a particular episode of contention, this study offers important insights into government-challenger relations in authoritarian regimes.
\end{abstract}

\section{Keywords}

Middle East - contentious politics - repression - concessions - authoritarian regimes - youth protest

Today, scholars of the Middle East widely agree that the Arab uprisings were sparked by youth movements that had long been mobilizing for political 
change. ${ }^{1}$ Survey evidence shows that one third of young Arabs participated in protests prior to the uprisings. ${ }^{2}$ At the same time, governments responded differently to the initial mobilizations, despite striking similarities in terms of activist profiles and political demands. In monarchies such as Morocco and Jordan, incumbent rulers swiftly offered concessions or even inclusion in the regime. ${ }^{3}$ In dominant-party regimes, such as Tunisia and Egypt, protests were violently suppressed. Yet, the causal mechanisms underlying these varying government strategies remain underspecified: what makes some authoritarian governments more likely to respond beneficently to political protest?

Contrary to conventional wisdom, this article argues that authoritarian government's strategies of dealing with dissent are not the result of some "autocratic intelligent design"4 reflecting the immediate interests of the incumbent ruler. Instead, they are determined by established patterns of domestic politics, including institutionalized interactions, existing linkages, and expectations between the actors involved. Drawing on relational approaches

1 See, for example, Mohammed Al-Momami, "The Arab 'Youth Quake': Implications on Democratization and Stability," Middle East Law and Governance 3/1-2 (2011): 159-70; Dina Shehata, "Youth movements and the 25 January revolution" in Arab Spring in Egypt, ed. Baghat Korany and Rabab El-Mahdi (Cairo: American University in Cairo Press, 2012), 105-24; Rabab El-Mahdi, "Egypt: A Decade of Ruptures," in Taking to the Streets: The Transformation of Arab Activism, ed. Lina Khatib and Ellen Lust (Baltimore: Johns Hopkins University Press, 2014), 52-75; Marc Lynch, "Introduction" in The Arab Uprisings Explained: New Contentious Politics in the Middle East, ed. Marc Lynch (New York: Columbia University Press, 2014), 7.

2 Michael Hoffmann and Amaney Jamal, "The Youth and the Arab Spring: Cohort Differences and Similarities," Middle East Law and Governance 4/1 (2012): 176. This finding is in line with earlier studies that have found young people to be more prone to protest behavior than any other age cohort. See, for example, Henrik Urdal, "A Clash of Generations? Youth Bulges and Political Violence," International Studies Quarterly 5o/3 (2006): 607-29; Ragnhild Nordås and Christian Davenport "Fight the Youth: Youth Bulges and State Repression," American Journal of Political Science, 57/4 (2013): 926-40. These results are particularly relevant in light of the fact that a majority of the region's population is under the age of thirty.

3 Hereafter, the term government will be used to describe "the group who controls the state." Patrick van Inwegen, Understanding Revolution (Boulder: Lynne Rienner, 2011), 7. By contrast, regime defines "the formal and informal organization of the center of political power, and of its relations with the broader society. A regime determines who has access to political power, and how those who are in power deal with those who are not." Robert M. Fishman, "Rethinking State and Regime: Southern Europe's Transition to Democracy," World Politics 42/3 (1990): 428.

4 Nathan J. Brown, "Advice for Youngsters: Do as I say, not as I did," in Reflections on the Arab Uprisings, POMEPS Studies, 10 (2014), 9. 
from contentious politics, I propose that government responses are shaped by three interrelated mechanisms, which operate on three distinct levels: First, institutionalization of political protest in the polity defines the extent to which protests follow established procedures. Institutionalization renders outcomes more predictable, thereby lowering levels of conflict and increasing the chances of beneficent responses. Second, external certification of the protest refers to recognized authorities' validation of the actors and their demands. By providing protesters with legitimacy, certification also renders beneficent responses more likely. Third, interest polarization between the claimants describes the extent to which opinions diverge with regards to the desired distribution of power. Where protesters aim at ousting or persecuting the government, the possibilities for compromise and subsequent beneficent responses are diminished.

These three mechanisms will be illustrated by looking at government responses towards youth protest before and during the Arab uprisings. The focus on youth is justified by their particular capacity for disruption and their role as "first movers" in 2011. ${ }^{5}$ Across the region, youth movements triggered mass contention by initiating "informational cascades" 6 about previously concealed discontent in society. Moreover, youth protests offer a good opportunity to study divergent government responses to similar instances of contention, as they share important commonalities in terms of demands, activist profiles, and repertoires of action. ${ }^{7}$ Empirical analysis will focus on the diverse cases of Morocco and Egypt: the Moroccan government responded beneficently to a range of the protesters' demands, while the Egyptian government opted for marginalization and repression. By comparing divergent cases, the study aims to develop theoretical arguments, which can be applied to spatially and temporally different contexts.

The empirical analysis is based on a detailed reading of news coverage, systematic consultation of secondary sources, and original interview data. The latter comprises twenty-four semi-structured interviews with senior officials

5 Adria Lawrence, "Repression and Activism among the Arab Spring's First Movers: Evidence from Morocco's February 2oth Movement," British Journal of Political Science 47/3 (2017): 699-718.

6 Susanne Lohmann, "The Dynamics of Informational Cascades: The Monday Demonstrations in Leipzig, East Germany, 1989-91," World Politics 47/1 (1994): 319-33.

7 Nadine Abdalla, "Youth movements in the Egyptian Transformation: Strategies and Repertoires of Political Participation," Mediterranean Politics 21/1 (2016): 44-63; Mohamed Madani, Driss Maghraoui and Saloua Zerhouni, The 2011 Moroccan Constitution: A Critical Analysis (Stockholm: International Institute for Democracy and Electoral Assistance, 2012). 
from state ministries and implementation agencies in 2013. This corresponds to the first government under Abdelilah Benkirane (Justice and Development Party) in Morocco and the interim government under Adly Mansour (Independent) in Egypt, which was installed after the coup d'état on July 3, 2013. Initial interviews were conducted with officials responsible for the formulation and implementation of youth-related policy in the Ministries of Youth, Labor and Social Development and their corresponding agencies. ${ }^{8}$ In Morocco, this additionally included the Ministry of Interior, the Ministry for Relations with Parliament and Civil Society, and the Ministry of Higher Education. A second phase added interviews at ministries and agencies that emerged as crucial in the first round. ${ }^{9}$ Interviews were held in French in Morocco, and in Arabic and English in Egypt, and transcribed for further analysis. To protect respondent confidentiality, interviewees were anonymized beyond their institutional affiliation. ${ }^{10}$

The remainder of the article will proceed as follows: The next section discusses existing research on government responses to political protest under authoritarianism. Then the causal mechanisms underlying beneficent responses will be specified. The following case studies present the opportunity to apply the theoretical framework to the empirical analysis of government responses to youth protests in Morocco and Egypt. Finally, the conclusion considers broader theoretical and empirical implications.

\section{Beneficent Government Responses to Political Protest Under Authoritarianism}

Scholars of authoritarianism generally agree that non-democratic regimes cannot persist by relying on repression alone; they also require a modicum of societal support. ${ }^{11}$ Constant repression of political dissent is not only costly, but

8 In Egypt, a number of interviewees held interim office as minister or vice-minister in the bureaucratic government following the 2013 coup d'état.

9 In Egypt, this included the Ministries of Finance and Planning, respectively. In Morocco, interviews were also conducted at the Sharifian Phosphate Office (OCP), the largest state company, and the Mohammed v Foundation.

10 All interview transcripts are on file with the author.

11 See, for example, Barbara Geddes, "What Do We Know About Democratization After Twenty Years?", 125; Jennifer Gandhi, Political Institutions under Dictatorship, 76; Johannes Gerschewski, "The Three Pillars of Stability: Legitimation, Repression, and Co-optation in Autocratic Regimes," Democratization 20/1 (2013): 21. 
can also increase mobilization in the long run. ${ }^{12}$ Therefore, to (re-)establish political support among actual or potential opposition groups, authoritarian governments often respond beneficently to their demands. ${ }^{13}$ Beneficent responses consist of either concrete economic or political concessions that cater to the challengers' demands, or their inclusion in the political process. ${ }^{14}$ While related, these two types of response are distinct in their logic: concessions, which range from spending on public or private consumption goods to the extension of political rights, grant concrete benefits in exchange for demobilization. On the other hand, inclusion has legitimizing benefits by offering activists or entire social movement organizations - that is organizations taking a coordinating role in the opposition movement - the possibility to henceforth pursue their interests within the legal political sphere. By setting incentives for protesting groups to demobilize, beneficent responses help to fragment opposition to the regime. ${ }^{15}$

Yet, the question remains: when do authoritarian governments respond beneficently to political protest rather than resorting to repression..$^{16}$ The comparative literature on authoritarianism suggests that domestic politics are strongly influenced by the subtype of authoritarian rule in a given country. Monarchies are less likely than republics to experience political instability, and

12 Christian Davenport, Carol Mueller, Hank Johnston, eds., Repression and Mobilization (Minneapolis: University of Minnesota Press, 2005).

13 Courtenay R. Conrad, "Constrained Concessions: Beneficent Dictatorial Responses to the Domestic Political Opposition," International Studies Quarterly 55 (2011): 1167-87.

14 Ibid. 1169-70; Ellen Lust-Okar, Structuring Conflict in the Arab World: Incumbents, Opponents, and Institutions (Cambridge: Cambridge University Press, 2005), 75.

15 Other authors have analyzed beneficent government responses in terms of different forms of co-optation, i.e., material and institutional-structural co-optation. For a discussion of this literature see Maria Josua, "Co-optation Reconsidered: Authoritarian Regime Legitimation Strategies in the Jordanian 'Arab Spring," Middle East Law and Governance 8/1 (2016): $32-56$.

16 Following Tarrow, political protest refers to "disruptive collective action that is aimed at institutions, elites, authorities, or other groups on behalf of the collective goals of the actors or of those they claim to represent". Sidney Tarrow, Struggle, Politics, and Reform: Collective Action, Social Movements, and Cycles of Protest (Ithaca: Cornell University Press, 1991), 11. In the context of authoritarian regimes, Bratton and de Walle have narrowed the definition to collective action in which "protesters make explicit demands for changes in political rights or rulership". Michael Bratton and Nicolas van de Walle, Democratic Experiments in Africa: Regime Transitions in Comparative Perspective (Cambridge: Cambridge University Press, 1997), 129. 
therefore make less use of repression. ${ }^{17}$ In a study comparing monarchies and dominant-party regimes, Lust-Okar and Jamal found important differences in the institutional management of opposition: liberalized monarchies tend to create institutions that balance political power among competing forces, whereas dominant-party regimes generate institutions that concentrate political power. ${ }^{18}$ This is because monarchies and dominant-party regimes differ fundamentally with regards to their bases of political power. Monarchs derive legitimacy from non-electoral sources and can therefore serve as political arbiters atop competing political forces. ${ }^{19}$ By contrast, the legitimacy of presidents is intertwined with popular politics; this involves a strong political party to penetrate society. ${ }^{20}$ Therefore, governments in dominant-party regimes cannot tolerate other strong political organization. This finding indicates that monarchs and presidents have different options when dealing with opposition movements.

Other scholars have proposed that divergent government responses to political protest are shaped by different elite constellations. Mass contention not only creates public disorder, it also provides opportunities for organized opposition to draw in new adherents and hereby strengthen their political leverage. In such moments, elite cohesion is crucial for regime survival. Where elite actors have divergent preferences and assessments regarding the use of coercion and reaching agreement with the opposition, divisions between "hardliners" and "softliners" can emerge. These divisions can lead to elite splits and ultimately result in regime collapse. ${ }^{21}$ Therefore, governments sometimes alter their strategies as protests evolve. For example, this shift was visible during the

17 See, for example, André Bank, Thomas Richter, and Anna Sunik, "Durable, Yet Different: Monarchies in the Arab Spring," Journal of Arabian Studies 4/2 (2014): 163-79; B. Todd Spinks, Emile Sahliyeh, and Brian Calfano, "The Status of Democracy and Human Rights in the Middle East: Does Regime Type Make a Difference?", Democratization 15/2 (2008): $321-41$.

18 Ellen Lust-Okar and Amaney Ahmad Jamal, "Rulers and Rules. Reassessing the Influence of Regime Type on Electoral Law Formation," Comparative Political Studies 35/3 (2002): 337-66.

19 Lisa Anderson, "Absolutism and the Resilience of Monarchy in the Middle East," Political Science Quarterly 106 (1991): 1-15.

$20 \quad$ Ellen Lust-Okar and Amaney Ahmad Jamal, "Rulers and Rules," 354-55; Beatriz Magaloni and Ruth Kricheli, "Political Order and One-Party Rule," Annual Review of Political Science 13 (2010): 123-43.

21 Guillermo O'Donnell and Phillip Schmitter, Tentative Conclusions about Uncertain Democracies, in Transitions from Authoritarian Rule, ed. Guillermo O'Donnell, Phillip Schmitter and Laurence Whitehead (Baltimore: Johns Hopkins University Press, 1986), 15-17; Adam Przeworski, Democracy and the Market: Political and Economic Reforms in Eastern Europe and Latin America (New York: Cambridge University Press, 1991), 51-94. 
2011 protests in Bahrain, where the softliner Crown Prince Salman bin Hamad $\mathrm{Al}$ Khalifa invited protesting groups to a national dialogue following a period of intense state violence. When the dialogue failed to produce results, the government returned to its repressive hardline approach. Other studies focusing on the events of 2011 insist on the importance of government-military relations for the outcome of the protests, i.e., whether the military agrees to fire upon protesters or not. ${ }^{22}$ However, all of these studies focus on elite behavior after the first government strategies failed and protests escalated. Because elite splits and military defection are not visible in the early stages of protest, they cannot explain initial government responses.

Finally, the literature on repression insists on the perceived threat to explain when governments resort to physical coercion. The link between levels of protest and repression is well established. ${ }^{23}$ Moreover, research suggests that the type of protest demands shapes the government's threat perception. ${ }^{24}$ Political protests targeting existing power structures pose a direct threat to the regime's legitimacy, and are therefore repressed. ${ }^{25}$ Protest activities focused on narrow demands, such as labor issues or specific policies, are less threatening and can potentially even serve regime maintenance by informing governments of citizen preferences. ${ }^{26}$ Yet, related studies have difficulties explaining why governments' use of repressive strategies varies in light of similar threats. Indeed, a recent study focusing on repression during the 2011 uprisings in Egypt and Bahrain concluded that divergent strategies were less due to the actual threathere operationalized as demands for political change and the level of mobilization - than the overall inclusiveness of the regime and the size of its base. ${ }^{27}$

22 Bellin, Eva, "Reconsidering the Robustness of Authoritarianism in the Middle East: Lessons from the Arab Spring," Comparative Politics 44/2 (2012): 127-49.

23 Jennifer Earl, Sarah A. Soule and John D. McCarthy, "Protest under fire? Explaining the policing of protest," American Sociological Review 68/4 (2003): 581-606; Christian Davenport, "State Repression and Political Order," Annual Review of Political Science 10 (2007): 1-23; Sabine C. Carey, Protest, Repression and Political Regimes: An Empirical Analysis of Latin America and Sub-Saharan Africa (New York: Routledge, 2009).

24 James C. Franklin, "Contentious Challenges and Government Responses in Latin America," Political Research Quarterly 62/4 (2009): 700-714.

25 Paul Y. Chang and Alex S. Vitale, "Repressive Coverage in an Authoritarian Context: Threat, Weakness, and Legitimacy in South Korea's Democracy Movement," Mobilization 18/1 (2013): 19-39.

26 Peter L. Lorentzen, "Regularizing Rioting: Permitting Public Protest in an Authoritarian Regime", Quarterly Journal of Political Science 8 (2013): 127-58.

27 Maria Josua and Mirjam Edel, "To Repress or not to Repress - Regime Survival Strategies in the Arab Spring," Terrorism and Political Violence 27/2 (2015): 289-309. 
In sum, the existing literature suggests that different regime structures, including the institutional setup and actor constellations, account for divergent government responses to political protest. However, related claims tend to remain restricted to a general level. To get to the concrete mechanisms that determine beneficent - or repressive - government responses to political protest, the next section draws on the comparative social movement literature. ${ }^{28}$ Doing so, it inserts a twist on the common analysis of contentious politics, which tends to take the movement rather than the government perspective.

\section{Institutionalization, External Certification, and Interest Polarization}

Scholars of contentious politics have long claimed that protest outcomes depend on the government and opposition's ability to compromise. Even if the government offers economic or political concessions to protesting groups, the success of its strategy will also depend on whether the latter accept or reject the offer. Drawing on the relational social movement literature, I propose that whether compromise is reached or not is shaped by three mechanisms on three distinct levels: institutionalization of political protest in the polity; external certification of the protest demands by legally recognized authorities; and interest polarization between claimants.

First, structural-relational approaches to political contention have demonstrated the impact of political institutionalization on political challengers' actions and the strategies that governments are likely to pursue. ${ }^{29}$ Institutionalization of political protest captures the degree to which such protests have become part of the conventional repertoire which citizens use to express their opinions about the regime and its policies, and to which the government and its agencies have established strategies of dealing with them. ${ }^{30}$

28 See for example Doug McAdam, John D. McCarthy, Mayer N. Zald, Comparative Perspectives on Social Movements: Political Opportunities, Mobilizing Structures, and Cultural Framings (Cambridge: Cambridge University Press, 1996).

29 Sidney G. Tarrow and David S. Meyer, "A Movement Society: Contentious Politics for a New Century," in The Social Movement Society: Contentious Politics for a New Century, ed. Sidney G. Tarrow and David S. Meyer (Lanham: Rowman and Littlefield, 1998), 1-28; see also Samuel P. Huntigton, Political Order in Changing Societies (New Haven and London: Yale University Press, 1968).

30 John D. McCarthy and Clark McPhail, "The Institutionalization of Protest in the United States," in The Social Movement Society: Contentious Politics for a New Century, ed. Sidney G. Tarrow and David S. Meyer (Lanham: Rowman and Littlefield, 1998), 83-110. 
By rendering different claimants' behavior more predictable, institutionalization lowers levels of conflict. This "taming" of political protest goes hand in hand with increased chances of reaching political compromise, and thus beneficent government responses. Inversely, low institutionalization inserts uncertainty into the process. In such contexts, governments will be more likely to suppress protests, and protesters will develop more confrontational claims and means of action. This can generate a vicious cycle: repression fuels dissent, which in turn, enflames repression. ${ }^{31}$ Thus, low institutionalization of political protest diminishes the chances for beneficent government responses.

Second, actor-centered approaches to contentious politics show that their outcomes also depend on third-party attitudes toward the protesters. ${ }^{32}$ Specifically, protests benefit from external certification, and thus "the validation of actors, their performances, and their claims by external authorities." ${ }^{33}$ Certification can occur on varying levels of intensity, ranging from recognition and endorsement to active engagement. ${ }^{34}$ From the government's perspective, certification provides information about compliance that adds weight to protesters' demands, especially if it involves politically relevant elites. When legally recognized actors - including political parties, interest groups, or religious authorities - validate protesting groups as legitimate bargaining partners, this increases those groups' political leverage. ${ }^{35}$ In times of low regime contention, the government can simply increase control and coercion of included elites to undermine such behavior. However, the uncertainty introduced by mass protests potentially opens opportunities for these elites to broaden their influence. Therefore, governments will be more likely to respond beneficently to political protest, when the latter signal their disposition to defect. ${ }^{36}$

Third, beneficent responses depend on the degree of interest polarization. Polarization refers to the "political and social space between claimants in a

31 William A. Gamson, Power and Discontent (Homewood: Dorsey, 1968).

32 Dingxin Zhao, "State-Society Relations and the Discourses and Activities of the 1989 Beijing Student Movement," American Journal of Political Science 44/1 (2000): 1595; Jennifer Earl, Sarah A. Soule and John D. McCarthy, "Protest under fire?".

33 Doug McAdam, Sidney Tarrow and Charles Tilly, Dynamics of Contention (Cambridge: Cambridge University Press, 2001), 121.

34 Katie Furuyama and David S. Meyer, "Sources of certification and civil rights advocacy organizations: the JACL, the NAACP, and crises of legitimacy," Mobilization 16/1 (2011): 102.

35 Ibid.

36 On strategies of (re-)strengthening the regime base, see Maria Josua, "Co-optation Reconsidered," 38-42. The argument can also be found in Ellen Lust-Okar, Structuring Conflict in the Arab World, 89 . 
contentious episode and the gravitation of previously uncommitted or moderate actors toward one, the other, or both extremes."37 In situations of high polarization, the moderate center is vacant and policy issues are filled with ideological content. In such situations, protest tends to be directed against the government, instead of at the government. No government will respond beneficently to protesters determined to topple it or even punish elites for past crimes. By contrast, low polarization facilitates moderation and compromise, and thus beneficent responses. Note that because protest movements are never homogenous, governments may seek to respond beneficently to moderate groups of protesters that are amenable to compromise, while repressing the rest. 38

While the above specified mechanisms are conceptually distinct, their results are clearly interrelated: institutional arrangements shape incentives for external certification; institutionalization and certification together impact polarization. Inversely, polarization impedes certification from established authorities, thereby lowering the chances of institutionalization. Empirically, the workings of these mechanisms are difficult to disentangle. The next two empirical sections evaluate how institutionalization, certification and polarization have affected protest dynamics and government responses in the divergent cases of Morocco and Egypt.

\section{Comparing Government Strategies towards Youth Protest in Morocco and Egypt}

The cases of Morocco and Egypt have served in previous comparisons of protest politics in the region. ${ }^{39}$ In 2011, these two "early risers" were among the first monarchies or republics, respectively, to experience protest demanding

37 Doug McAdam, Sidney Tarrow and Charles Tilly, Dynamics of Contention, 45 .

38 Hugo Gorringe and Michael Rosie, "It's a Long Way to Auchterarder! 'Negotiated Management' and Mismanagement in the Policing of G8 Protests," The British Journal of Sociology 59/2 (2008): 187-205.

39 Frédéric Vairel, "Protesting in Authoritarian Situations. Egypt and Morocco in Comparative Perspective", in Social Movements, Mobilization, and Contestation in the Middle East and North Africa, ed. Joel Beinin and Frédéric Vairel (Stanford: Stanford University Press, 2011), 27-42; Florian Kohstall, "From Reform to Resistance: Universities and Student Mobilisation in Egypt and Morocco before and after the Arab Uprisings", British Journal of Middle Eastern Studies 42/1 (2015): 59-73; Kressen Thyen and Johannes Gerschewski, "Legitimacy and protest under authoritarianism: explaining student mobilization in Egypt and Morocco during the Arab uprisings," Democratization (2017). 
regime change. ${ }^{40}$ This study compares government responses to these initial demonstrations, which were still similar with regards to the type of activists and their demands. Indeed, the protests developed distinct dynamics as they unfolded. In Egypt, the core activists and their concrete demands became marginal in the subsequent mass mobilization. ${ }^{41}$ While the Egyptian protests became dominated by nationalist attitudes, the Moroccan protests remained driven by discontent with political institutions. ${ }^{42}$

The study follows a confirmatory, diverse case selection strategy. This approach selects two or more cases that span the continuum of either the dependent or the independent value to maximize variance. ${ }^{43}$ The cases of Morocco and Egypt represent extreme values on the dependent variable: while Morocco responded beneficently to the initial youth protests in 2011, the Egyptian government opted for repression. The following analysis aims not only to illuminate the empirical cases, but also to demonstrate the utility of the conceptual framework beyond these cases. Each case study commences with a short overview of the political context, before examining government responses to youth protest prior to and during the uprisings.

\section{Beneficent Government Responses to Youth Protests in Morocco: Institutionalization of Political Protest, External Certification, and Moderate Interest Polarization}

In Morocco, political youth protest emerged in the context of a liberalized monarchy. Since the 199os, Morocco's so-called "processus démocratique" has become one of the main themes in political discourse. ${ }^{44}$ However, despite undeniable steps toward political pluralization, politics remain dominated by

40 The case selection thus excludes cases that could have benefited from learning processes, which are limited by institutional and power settings at different levels. André Bank and Mirjam Edel, "Authoritarian Regime Learning: Comparative Insights from the Arab Uprisings," GIGA Working Paper, 274 (2015).

41 Zachary C. Steinert-Threlkeld, "Spontanous Collective Action: Peripheral Mobilization during the Arab Spring," American Political Science Review 111/2 (2017): 396-398.

42 Thyen and Gerschewski 2017, "Legitimacy and Protest," 11.

43 Jason Seawright and John Gerring. "Case Selection Techniques in Case Study Research," Political Research Quarterly 61/22 (2008): 294-308.

44 Abdeslam Maghraoui, "Depoliticization in Morocco," Journal of Democracy 13/4 (2002): 29; also see Kressen Thyen, "Promising Democracy, Legitimizing Autocracy? Perceptions of Regime Democraticness among University Students in Morocco", Zeitschrift für Vergleichende Politikwissenschaft 11/2 (2017). 
the royal palace. The monarch controls the administration and the parliament through a network of royal counsellors, and all elected parliamentarians and higher state officials swear allegiance (bay'a) to him in a symbolic act of servitude. ${ }^{45}$ Consequently, the involvement of established political actors tends to follow the monarchy's official or presumed position. ${ }^{46}$ This specific setup is not least related to the creation of a particularly effective "divided political environment," in which the monarch remains ultimate arbiter in a fragmented political landscape. ${ }^{47}$ In this context, the government also expanded freedoms of expression, association and assembly. This created an institutional structure in which grassroots activism on political issues became possible as long as it did not touch upon the regime's fundamental interests, namely the monarchy, religion, and the Western Sahara. ${ }^{48}$ Opposition groups have adapted to this political environment by pushing for specific reforms whilst avoiding the regime's "red lines." Prominent examples are the women's rights movement and the reform of the Moroccan family code (Mudawana), the Amazigh movement and the recognition of indigenous rights, or the human rights movement and the creation of a commission to determine compensation for victims of forced disappearances during the "years of lead" under the previous king. As a result, political protest today constitutes an established means of attaining material and political benefits even for the legally recognized opposition. While individual cases of police violence are frequently reported, mass coercion has become minimal.

The above patterns are mirrored in Morocco's youth politics. On the formal side, the government has attempted to increase youth participation in existing participatory structures. In 2002, it reformed the minimum age for voting from 20 to 18 years to "bring new blood into the practice of democracy."49 In 2006,

45 Mohamed Madani, Driss Maghraoui and Saloua Zerhouni, The 2011 Moroccan Constitution.

46 Abdeslam M. Maghraoui, "Democratization in the Arab World? Depoliticization in Morocco," Journal of Democracy 13/4 (2002): 24-32.

47 Ellen Lust-Okar, "Divided They Rule: The Management and Manipulation of Political Opposition," Comparative Politics 36/2 (2004): 159-179.

48 Mohamed Tozy, "Représentation/Intercession. Les Enjeux de Pouvoir dans les 'Champs Politiques Désamorcés' au Maroc," in Changements Politiques au Maghreb, ed. Michel Camau (Paris: Editions du CRNS, 1994), 153-168. Note that the government has employed repression where protests crossed these limits. For example, 800 people were arrested in December 2000 for participating in unauthorized demonstrations to mark the annual Human Rights Day. Freedom House, "Freedom in the World 2002: Morocco," https:// freedomhouse.org/report/freedom-world/2002/morocco. 
the government created the Institute for Youth and Democracy (Institut de la Jeunesse et de la Démocratie), under the auspices of the Ministry for Youth and Sports to strengthen the youth wings of existing political parties. Moreover, diverse state organizations, foundations and international donor agencies have provided infrastructure and support to encourage youth activism in civil society organizations. This fostered a relatively stable network of youth organizations, the larger of which enjoy national representation through a number of federations and national youth unions.

While youth protests emerged in the late 1980s and 1990s, Morocco had no encompassing youth protest movement before 2011. First protests occurred mainly within universities or in grassroots movements focused on development and labor issues. The Movement of Unemployed Graduates (Mouvement des diplômés chômeurs) is arguably one of the most influential of these movements. The movement emerged in reaction to the privatization of state companies and slimming down of public administration in the context of structural reforms, demanding that the government tackle rising unemployment by reviving job creation in the public sector. Established opposition parties and unions supported the initiative in its early years. ${ }^{50}$ In response to joint pressure from the protest movement and established opposition, King Hassan II created the National Council for Youth and the Future (Conseil National de la Jeunesse et de l'Avenir, CNJA), to assist in the development of youth employment policies. ${ }^{51}$ Habib El Malki, leader of the oppositional Socialist Union of Popular Forces (USFP), headed the council. When the government announced further structural reforms in 1995, the movement deployed more radical forms of contention, which varied from sit-ins to hunger strikes and squatting. Following the arrest and sentencing of 26 protesters in El Jadida, opposition parties and established human rights organizations condemned the violent intervention by police forces. This added further impetus to the movement. In 1997, Prime Minister Abdellatif Filali personally met with leading activists and promised to address their demands. The following years saw several recruitment agreements between the government and the unemployed graduates, based on nominal lists established by the movement. Moreover, the Ministry of Employment and Vocational Training began to develop specialized training

50 Montserrat Emperador Badimon, "Unemployed Moroccan University Graduates and Strategies for 'Apolitical' Mobilization," in Social Movements, Mobilization and Contestation in the Middle East and North Africa, ed. Joel Beinin, Frédéric Vairel (Stanford: Stanford University Press, 2011), 227.

51 Dahir $\mathrm{n}^{\circ}$ 1-90-19o du 20/02/1991 portant création du Conseil de la jeunesse et de l'avenir (СNJA) (во п ${ }^{\circ} 4088 \mathrm{du}$ 06/03/1991). 
and job-creation programs, which are implemented to this day by the national employment agency (ANAPEC). As confirmed in the interviews, the Ministry's focus on unemployed graduates was directly related to their particular ability to exercise pressure on the government. ${ }^{52}$ Since then, the movement has moderated its demands to adopt an "apolitical" stance and was legally recognized as the Association Nationale des Diplômés Chômeurs du Maroc (ANDCM) in 2003 .

The government also responded favorably to youth involvement in socioeconomic protests. While legal opposition and civil society have been suspicious of mass mobilization in the past decades, they have still recognized the social agenda at the heart of these protests and gained political leverage from the mobilizations. In 2000, the Agency for Social Development (Agence du Développement Social, ADS) was created, under the auspices of the Ministry for Social Development. The Agency's long-standing director, Mohamed Najib Guedira, was a leading figure in the labor movement and counsellor of the 1998 "government of change." To this day, the agency implements social development initiatives, including financial support for micro enterprises by youth and the promotion of social dialogue. In addition, influential foundations have taken up the focus on youth, such as the Mohammed v Foundation for Solidarity, which was established by present King Mohammed VI in 1999. In this context, it is interesting to note that even incidents of political violence have been framed in social terms. For example, in response to the 2003 suicide bombing carried out by 14 young men from the shantytowns of Casablanca, the founder of the large development association Marocains Pluriels publicly stated in an interview that "we are all responsible" for the underlying youth marginalization. ${ }^{53}$ In the past fifteen years, projects aimed at preventing the marginalization and radicalization of young people have soared, especially with the launch of the National Initiative for Human Development (INDH) in 2005. However, these programs and initiatives remain geographically limited, targeting only specific communities within the country.

The emergence of the 2011 youth protests, led by the February 20 Movement, has to be placed in this specific political context. The Movement constituted a novelty insofar as it was the first to transcend the narrow demands of student or unemployed movements, and the first to explicitly address the

$5^{2}$ Interviews by the author at the Ministry of Employment and Vocational Training, ANAPEC, and ADS, Rabat, August/September 2013.

53 Bachir Hajjaj, "Nous sommes tous responsables," Aujourd'hui Le Maroc, May 30, 2003, http://aujourdhui.ma/societe/nous-sommes-tous-responsables-29927. 
issue of democratic participation. ${ }^{54}$ Its overarching demand consisted in the establishment of a parliamentary monarchy, including a democratic constitution, an elected government, separation of powers, the trial of individuals implicated in acts of corruption, recognition of the Amazigh heritage, and the liberation of all political prisoners. In addition, the movement called for the integration of unemployed graduates into the labor market, the introduction of a minimum wage and political measures against the high cost of living, and the extension of public services to the entire population. ${ }^{55}$ In doing so, the Movement transgressed previous divisions between political camps, uniting youth activists from various political parties, community committees, human rights and Amazigh associations, trade unions, and the Islamist Al-Adl wa Al-Ihsan movement. ${ }^{56}$ Moreover, members of other groups, such as the unemployed graduates and unaffiliated sympathizers, promptly joined its protests. The government has recognized the interconnectedness of the Movement's political and social demands, as a senior official at the ADs explained:

We are currently experiencing a growing consciousness among youth on the social and political level: they are interested in politics. Contrary to what is often said, they do not only want to work, but their demands on the socio-economic level reflect questions related to dignity and labor rights. [...] [And] there is the political dimension, how we will integrate young people in political decision-making, where such channels are absent. $^{57}$

Yet, the movement also connected to a previous protest tradition. In the words of another official, "we had protests well before, and there are protests that continue, these problems are not new."58 The explicit link of the Movement's agenda to previous political struggles provided it with some legitimacy from established opposition. Certainly, many of the established parties and civil

54 Driss Maghraoui "Constitutional Reforms in Morocco: Between Consensus and Subaltern Politics," The Journal of North African Studies 16/4 (2011): 688.

55 Thierry Desrues, "Moroccan Youth and the Forming of a New Generation: Social Change, Collective Action and Political Activism," Mediterranean Politics 17/1 (2012): 32.

56 Mohamed Madani, Driss Maghraoui and Saloua Zerhouni, The 2011 Moroccan Constitution, 10-11.

57 Interview by the author at the ADs, Rabat, September 2013 (author's translation).

58 Interview by the author at the Ministry of Employment and Vocational Training, Rabat, August 2013. This was also confirmed in an interview by the author at the Ministry of Interior, Rabat, September 2013 . 
society organizations refrained from joining the protests. ${ }^{59}$ At the same time, many of the protesters also held membership in legally recognized organizations and political parties, thus creating individual ties. ${ }^{60}$ Reputable individuals from established civil society groups formed a 16o-person National Council of Support of February 20 Movement, further recognizing and endorsing the movement. Lastly, journalists, bloggers, and activists created the online resource Mamfakinch (No Concessions) to cover the protests and have reached wide audiences in Morocco and beyond. This added to the movement's credibility and public support.

Furthermore, the February 20 Movement conformed to a number of established protest logics. Most importantly, it addressed its demands for regime change to the incumbent government instead of mobilizing to immediately overthrow the incumbent. Specifically, it demanded of the "royal institution to make the necessary changes to the political system, in a way that allows Moroccans to rule themselves." ${ }^{\prime 1}$ The movement's call for a parliamentary monarchy reduced polarization of interests between the protesters and the government, as the latter was not to be completely deprived of political power. This offered opportunity for compromise, as a senior official explained:

The protests still remained in certain limits, $[\ldots]$ there was only a minority that wanted to change the system [and abolish the monarchy]. But if the youth starts to really demand a change of the system that would be the knockout [...]. The King is the guarantor of stability in Morocco, in contrast to other countries in the region. ${ }^{62}$

Within less than three weeks of the first protest, Mohammed vi gave a speech to the nation in which he acknowledged the need for a social charter and constitutional reform, particularly addressing the "committed political parties and

59 Emanuela Dalmasso, "Surfing the Democratic Tsunami in Morocco: Apolitical Society and the Reconfiguration of a Sustainable Authoritarian Regime," Mediterranean Politics 17/2 (2012): 228.

6o Nadine Sika, "Ambiguities of student activism, authoritarianism and democratic attitudes: the cases of Egypt and Morocco," The Journal of North African Studies 22/1 (2017): 35-59.

61 Translation as cited in Anja Hoffmann and Christoph König, "Scratching the Democratic Façade: Framing Strategies of the 20 February Movement," Mediterranean Politics 18/1 (2013): 15 .

62 Interview with a senior official in a private capacity by the author, Rabat, August 2013 (author's translation). 
trade unions, and [...] Our ambitious youth." ${ }^{63}$ The concessions' announcement initiated a process of gradual demobilization, as protesters waited for the government to follow up on its promises.

Subsequently, the government made a number of economic and political concessions. To start with, it created 3,400 new public administration positions, granted civil servants the highest salary increase in Moroccan history up to 35 percent - and increased the minimum salary in the private sector. ${ }^{64}$ It also increased the number of scholarships at public universities, which traditionally constitute an important base for protest mobilization. The Ministry of Employment and Vocational Training announced an extension of existing employment and training programs to youth without university diplomas. ${ }^{65}$ The government also offered economic benefits to other youth groups that had started to mobilize during the unfolding protests. Following youth protests at the work sites of the Sharifian Phosphate Office (OCP), the state-run company responded with 5,00o ad-hoc recruitments. Additionally, it financed 15,000 scholarships to provide vocational training for young people in the region. ${ }^{66}$ The government further published a new National Integrated Youth Strategy (SNIJ), developed by the Ministry of Youth and Sports in conjunction with other national authorities and the World Bank. The practical significance of this strategy remains hotly debated in official circles, as some consider it a mere "politique spectacle." 67

The government also made a number of political concessions, even if these remained far off from the kind of democratic reforms envisioned by the Movement's core activists. On April 14, 2011 the monarch granted pardon to scores of political prisoners, hereby answering to one of the movement's principal demands. The revised constitution of July 29, 2011 includes a number of human rights that were formerly not recognized and grants Amazigh the status of an official language. Moreover, it specifies that the Prime Minister must be chosen from the party that won the elections, extends parliamentary powers, and recognizes the status of the opposition parties. ${ }^{68}$ While the February 20 Movement continued to mobilize against the constitutional reform it deemed

63 Mohammed vi, "Discours adressé par SM le Roi à la Nation," March 9, 2011.

64 The minimum salary only benefits those employed in the formal economy, thus excluding the 88 percent of youth employed in the informal sector (cf. World Bank 2012).

65 Interview by the author at the Ministry of Employment and Vocational Training, Rabat, August, 2013.

66 Interviews by the author at the OCP, Rabat and Casablanca, September 2013.

67 Interview by the author at the ADs, Rabat, September 2013.

68 Mohamed Madani, Driss Maghraoui and Saloua Zerhouni, The 2011 Moroccan Constitution, 37 . 
"undemocratic," the government's concessions had siphoned off segments of the movement's supporters. Significantly, this resulted in decertification of the movement's political demands by oppositional groups with more moderate preferences.

Finally, the government undertook a number of efforts to politically include organized youth that had mobilized in the protests. With an eye to youth involvement in political parties, the government introduced a youth quota in the national parliamentary elections. Moreover, the activities of the National Institute for Youth and Democracy were revived under a new director, Ismael El Hamraoui, who had been a youth member of the Forum des Alternatives Maroc - a prominent civil society organization that had endorsed the protest movement. In the context of constitutional reform, selected youth activists were called on to participate in the consultation process of the constitutional committee. As a result of this process, the 2012 constitution stipulates the creation of a Consultative Council of Youth and of Associative Action, which provides appointed members an institutional framework to express their policy preferences. Rather than constituting a democratic institution, the planned Council primarily caters to the particular interests of individual organizations and activists, strengthening their links to the government.

By selectively responding to the different demands voiced by the February 2o Movement, the government has been able to minimize outright repression during protest events. Yet, this does not mean that repression has been absent; leading activists unwilling to moderate their demands have been repeatedly harassed by security forces. ${ }^{69}$ Following constitutional reform, this repression was paralleled by official discourse discrediting the Movement: questions of loyalty to the monarchy and the national reform project have emerged in a pronounced manner since $2012 .^{70}$ At the same time, counter-movements as the March 9 Youth Movement and the Young Royalists begun to mobilize against the Movement. This has created a symbolic divide between activists that are "with" or "against" the official reform project. The February 20 Movement has since been depicted as lacking a political agenda and pursuing goals detrimental to national cohesion while others - including youth involved in demonstrations over social and cultural issues - have been presented as "ambitious" or constituting a "new generation of Moroccans" concerned with the future of their country.

69 Emanuela Dalmasso, "Surfing the Democratic Tsunami in Morocco."

70 Mohammed vi, "Discours de SM le Roi adressé à la nation à l'occasion du 39 ème anniversaire de la Marche Verte," November 6, 2014. 


\section{Repressive Government Responses to Youth Protests in Egypt: Low Institutionalization, Lack of Certification, and High Polarization}

In Egypt, youth protests have developed in a different political context. While the country moved from a populist authoritarian regime under Nasser to a liberalized neo-patrimonial regime under Mubarak, the army has remained the backbone of each regime. Prior to 2011, the recruitment of political personnel was based on their adherence to the National Democratic Party (NDP). This created a particular type of personal rule in a dominant-party system; strong alternative political organization posed an immediate challenge to the regime. To secure the regime's party-personalist basis, the government relied on crude divide and rule strategies that concentrated power with the ruling party, and led to high polarization between the Islamist and liberal opposition. ${ }^{71}$ In this political environment, the government set strong incentives to contain protests strictly within the socio-economic realm, rewarding narrow and depoliticized demands with salary concessions or the maintenance of state subsidies. Unauthorized political protest, on the other hand, was deterred through a severe association law and harsh intervention by security forces. This created two distinct types of protest: on the one hand, depoliticized protests and strikes that avoided crossing the line into openly political activity occurred in exchange for economic concessions. On the other hand, there were political protests transgressing the boundaries of the regime, which found little support among legally legitimized authorities and directly targeted the president.

These patterns of participation and protest were reflected in Egypt's youth politics. In the effort to tie a greater number of youth to the regime, the government encouraged partisan and civil society participation in organizations loyal to the regime. In 2002, the ruling NDP established a youth committee and assigned young cadres to leading positions; other registered parties followed its example. ${ }^{72}$ The National Council for Youth, which was the precursor to the current Ministry of State for Youth Affairs, offered training for youth active in political parties, government administration, and non-governmental organizations. In addition, the government encouraged youth engagement in developmental organizations with close ties to state ministries and youth clubs. However, total levels of youth engagement remained low. ${ }^{73}$

\footnotetext{
$71 \quad$ Ellen Lust-Okar, Structuring Conflict in the Arab World.

72 Nadine Sika, "Youth Political Engagement in Egypt: From Abstention to Uprising," British Journal of Middle Eastern Studies 39/2 (2012): 181-99. 
With regards to protest politics, the institutionalized divide between socioeconomic and political protest also impacted youth mobilization. Young people were involved in labor strikes and protests against high unemployment and rising food prices. When protesters refrained from making political demands, the government sporadically ceded to salary concessions and upheld subsidies. These concessions targeted the general population, as a government official explained:

The policies that have a generic nature, that cover the entire country, are the policies that do generate the greatest benefits to the youth and everybody else $[\ldots]$, the male and female, the poor and the middle class, and so on. [...] Programs that target the youth are useful but limited by definition, while programs that do not target the youth but the entire population, their policies have a very high pay off. ${ }^{74}$

Hence, there were only a few youth-specific initiatives in the fields of unemployment and social exclusion, and these often benefited from international funding. For example, in 2007 the cabinet and UNDP jointly created the Social Contract Center (SCC), which conducts specific training and job-creation programs for university students and marginalized youth in rural areas. ${ }^{75}$

The apolitical socio-economic protests and related government responses stand in stark contrast to the conflictual youth protests. The most prominent youth movement prior to the 2011 uprisings was the youth arm of the Kifaya (Enough) Movement, which had formed in 2004 in response to Mubarak's attempt to nominate his son as the next presidential candidate. The selfproclaimed Youth for change mobilized against Mubarak, political corruption, and state violence. Their demands went "far beyond accepted limits of mobilization by legal opposition parties." ${ }^{76}$ Consequently, external authorities neither recognized nor endorsed the movement's demands. Likewise, youth activists strongly denied any alleged links to established political parties or civil society organizations, which they regarded as obsolete and corrupt. Interestingly

74 Interview by Nadine Sika at the Ministry of Finance, Cairo, November 2013.

75 Note that the impact of these programs has been limited due to the poor commitment from local authorities, service providers and potential employers. Interview by the author at the scc, Cairo, December 2013.

76 Frédéric Vairel, "Protesting in Authoritarian Situations. Egypt and Morocco in Comparative Perspective", in Social Movements, Mobilization, and Contestation in the Middle East and North Africa, ed. Joel Beinin and Frédéric Vairel (Stanford: Stanford University Press, 2011), 38 . 
enough, the movement's confrontational stance did not immediately prompt substantial repression. Protests were largely ignored, as long as they remained small in size and geographically confined to the capital city. ${ }^{77}$ However, when youth activists began joining sectoral protests - such as the judges' protests in 2006 - thereby inserting a political dimension, the government launched widespread repression. This strategy was initially successful, and Youth for Change disappeared for about two years. It reemerged under the name of the April 6 Movement in 2008, when youth activists decided to join massive labor strikes in El-Mahalla El-Kubra. Again, the government responded with repressive measures that targeted youth activists and workers alike, not least to serve as a warning to workers to avoid further politicizing their protests. Since then, the government has controlled youth protests by sealing off entire areas of the city, police violence, imprisonment, or even torture. Repeated experiences of violence have increased radical sentiments among youth activists, creating an antagonistic relationship between the government and protesters.

The 2011 protests emerged against this particular background of polarization. By calling on Egyptians to take to the streets on January 25 - Police Day and national holiday - the April 6 Movement created a symbolic link to the "second revolution" that had begun on January 25, $195^{2}$ and led to the ouster of King Farouk several months later. On February 6, 2011, participating youth groups released a joint manifesto summarizing their demands: the immediate resignation of President Mubarak, dissolution of the parliament, establishment of a transitional government, a new constitution respecting the principles of freedom and social justice, prosecution of those responsible for police killings, and immediate release of detainees. The statement further specified that there would be no negotiations until Mubarak's departure and that negotiations would only be concerned with the transfer of political power. ${ }^{78}$ While the overarching aim of the protest - regime change - was the same as in Morocco, the youth protests in Egypt were thus explicitly directed against, rather than at the government.

As in the past, protesters refused any ties to included political elites, which they considered to be part of the problem. In contrast to Morocco, there were thus no moderating groups between the government and protesters. Stark

77 On the strategy of ignoring see Dina Bishara, "The Politics of Ignoring: Protest Dynamics in Late Mubarak Egypt," Perspectives on Politics 13/4 (2015): 958-75.

78 "Statement of the April 6 Movement Regarding the Demands of the Youth and the Refusal to Negotiate with any Side," Jadaliyya, February 6, 2011. (http://www.jadaliyya.com/pages/ index/579/statement-of-the-april-6-movement-regarding-the-demands-of-the-youth -and-the-refusal-to-negotiate-with-any-side). 
interest polarization with regards to the future distribution of power left little room for compromise. In response to the demonstrations of the April 6 Movement, the government sent out the Central Security Forces, who used tear gas, water cannons, and physical violence in an attempt to disperse the protesters. However, in comparison to the past, repression backfired and drew wider segments of society to the streets. As an official explains, this took the government by surprise:

A revolution is never something that is expected, if not there would be no revolution. Then it would be like evolution. [...] Even in the first days of the revolution we did not see it as a revolution, but as a demonstration, like any other demonstration. [...] So it just escalated and it happened. ${ }^{79}$

Only when Mubarak saw himself confronted with rising pressure on the streets and a military leadership that put its own interests over loyalty to him, did he address "the youth of Egypt" to announce that he would meet their "legitimate demands." 80 However, the protesting groups refused to negotiate with the government, leading to Mubarak's forced resignation on February 11, 2011.

In sum, differences with regards to institutionalization, certification, and interest polarization have resulted in divergent government responses to political youth protest in Morocco and Egypt. This holds despite the fact that in both countries the protesters demanded a change of regime, i.e., a parliamentary monarchy and a representative democracy, respectively. Yet, the political context in Morocco paved the way for a more moderate youth movement that directed its demands at the government, to which the latter responded through a mix of partial concessions, selective inclusion and targeted repression. In Egypt, the political context had brought about a youth movement that protested against the government. Here, political concessions or even inclusion under the current government were inconceivable on both sides.

\section{Outlook: Responding to Political Protest in Times of Transition}

The aim of this study was to explain variations in initial government responses to the 2011 protests. Therefore, the above analysis focused on the strategies deployed in Egypt's dominant-party regime before Mubarak was ousted.

79 Interview by the author at the Ministry of Finance, Department for Economic Justice, Cairo, December 2013.

8o Hosni Mubarak, "Speech to the Nation," Cairo, February 10, 2011. 
However, it is worth examining how government strategies evolved in the ensuing transition period, which offered a period of "de-institutionalization," 81 opening windows of opportunity for new political practices and strategies. Indeed, the election of the Islamist President Mohamed Morsi of the Freedom and Justice Party (FJP) led to a shift in government responses to youth protests. Following its inauguration, the Islamist government organized dialogue sessions with different groups of youth activists to discuss their positions and demands. Moreover, it started a political awareness program on the new constitution, implemented by the scc. Due to an increase in international aid, the government was also able to extend job-creation programs. ${ }^{82}$ Following a conference on youth inclusion in December 2012, the Social Fund for Development (SFD) initiated specific programs in the areas of youth employment and financial inclusion. Conversely, levels of repression decreased in the first months of Morsi's reign. However, mounting political polarization between the then ruling Islamists and the liberal opposition stalled dialogue between secular-leaning youth activists and the government. The youth movement became increasingly fragmented and marginalized, as the political game came to be dominated by the political arm of the Muslim Brotherhood and powerful state actors, such as the military, judiciary, and parts of the bureaucracy. ${ }^{83}$ The mounting tensions between the president's supporters and opponents fueled violent clashes across Egypt, with state security forces using excessive violence reminiscent of the Mubarak era. In 2013, state security began to support mobilization against Morsi by the newly formed Tamarod (Rebellion) Movement. ${ }^{84}$ Following large demonstrations on the anniversary of Morsi's presidential inauguration on June 30, the military launched a coup on July 3, which paved the way for the presidency of former army general Abdel Fattah al-Sisi.

Following the establishment of the military regime, dialogue sessions were quickly abandoned and youth activists contesting the military government faced increasing repression by the state security forces. ${ }^{85}$ Moreover, the

81 Frédéric Volpi "Explaining (and re-explaining) political change in the Middle East during the Arab Spring: trajectories of democratization and of authoritarianism in the Maghreb," Democratization 20/6 (2013): 970.

82 Interview by the author at the ScC, Cairo, December 2013 .

83 Marina Ottaway, "Democratic Transitions and the Problem of Power," Middle East Program Occasional Paper Series (Spring 2014).

84 On the role of the state security forces in the Tamarod campaign, see Marina Ottaway, "Democratic Transitions and the Problem of Power," 3.

85 Nadine Abdalla, "Youth movements in the Egyptian Transformation"; Amnesty International, “Generation Jail. Egypt's Youth go from Protest to Prison," MDE 12/1853/2015 (June 2015). 
military government has returned to the strategy of dividing socio-economic and political issues by conferring legitimacy only to the former. Shortly after the coup, it announced a 71 percent increase in the minimum salary of state employees, and promised to follow up on this with legislation for the private sector. By contrast, no political concessions or inclusionary offers have been made. Political activists have been arrested, imprisoned, forcefully disappeared, and tortured. In the year following the ouster of Morsi, more than 1,400 demonstrators were killed and there have been mounting reports of ill treatment and torture of detainees. ${ }^{86}$ The repression targeted supporters of the defunct president, but also secular-leaning youth groups. In an interview conducted in November 2013, a government official explains the hard stance towards political protest:

There are two types [of protesters]. There are those who have a legitimate reason to demonstrate, either demanding rights that they are denied or [because] they disagree with a decision taken by government; and this is all acceptable. [...] Then, there are those who don't like you ... They don't like the way society is organized, and they want something else. They want another society. That's a tough one. That's a different one. They are not playing by the rules of the game. They are playing by different rules that suit them. That is a disagreement on cohabitation, and that's different. Obviously, we all must live together, and we all have to have common rules [...]. [T] o say I don't want to play by these rules and I want other rules and you're a minority, then you don't have the right. ${ }^{87}$

In 2014, the April 6 Movement was officially banned.

\section{Conclusion}

Comparing government responses to youth protest in Morocco and Egypt before and during the 2011 uprisings showed that the initial reactions were not simply the result of strategic miscalculations by Mubarak or the "smartness" of

86 Amnesty International, "Egypt: New Leader Faces Rights Crisis, Should Not Ignore Worst Situation in Decades," Press Release, June 9, 2014 (https://www.amnesty.org/en/press -releases/2014/o6/egypt-new-leader-faces-rights-crisis-should-not-ignore-worst -situation-deca/).

87 Interview by Nadine Sika at the Ministry of Finance, Cairo, November 2013. 
King Mohammed VI. ${ }^{88}$ They followed preexisting patterns of political contention, shaped by divergent degrees of protest institutionalization, external certification, and interest polarization. In light of relatively persistent institutions and conventions in dealing with protest, it was inconceivable that the Moroccan government would open fire on the youth activists, or that the Egyptian government would offer benefits to its challengers.

These results advance our knowledge on government responses to political protest, and particularly the 2011 uprisings, in several aspects. First, the present findings contribute to the literature on monarchies, by showing why they tend to respond beneficially: because monarchies tend to balance political power, they can institutionalize certain forms of political protest, which opens room for external certification and lowers polarization. While this "taming" of contentious politics lowers levels of repression, it mirrors the dilemma postured by McCarthy and McPhail who state that protest potentially loses its force through institutionalization. ${ }^{89}$ Paradoxically, it thus appears that monarchies are more resilient to political protest precisely because they leave greater room for regime contention. Note that this finding does however not apply to monarchical regimes per se. Research comparing monarchies in the region has shown that they reacted quite differently to the challenges of the 2011 uprisings based on preexisting regime variations. ${ }^{90}$

Second, and relatedly, these results demonstrate why governments in dominant-party regimes tend to be more dependent on repression once protests erupt. Because alternative political organization directly undermines the government's legitimacy, dominant-party regimes cannot offer concessions or inclusion to challengers in the same way as regimes in which the ruler is not beholden to elections. If the ruling party loses influence, the government is threatened as well. In such a high-stake conflict, giving into protesters' demands is virtually suicidal. Research indicates that this dilemma increases in military regimes, where alternative means of legitimation are even less prevalent than in dominant-party regimes. ${ }^{91}$ Recent developments in Egypt appear to confirm this observation, as repression under the al-Sisi government has

88 Saloua Zerhouni, “'Smartness' Without Vision. The Moroccan Regime in the Face of Acquiescent Elites and Weak Social Mobilization," sWP Comments 11 (February 2014).

89 John D. McCarthy and Clark McPhail, "The Institutionalization of Protest."

9o André Bank, Thomas Richter, and Anna Sunik, "Durable, Yet Different."

91 Christian Davenport, "State Repression and the Tyrannical Peace," Journal of Peace Research 44/4 (2007): 485-504. 
sky-rocked. Increased repression, however, is likely to lead to militant and potentially violent backlash in the future. ${ }^{92}$

In light of the Arab uprisings, concessions and inclusion may appear "safer" than violent suppression of political protest. However, one should be careful when drawing any conclusion regarding the long-term effects of beneficent strategies. It is well known that concessions can encourage oppositional forces to press for further change. ${ }^{93}$ Moreover, moderation of political demands does not necessarily mean that opposition forces also moderate their true preferences. ${ }^{94}$ Emboldened regime opponents can raise the bar for compromise as their political leverage increases, which can become problematic when the government is no longer willing to liberalize. Recent political developments in Morocco indicate that the political reform process has stalled, "potentially undermining the very bases of the kingdom's domestic stability." 95

\section{Acknowledgements}

This research was conducted as part of the project "Arab Youth: From Engagement to Inclusion?" funded by Volkswagen Foundation (AZ 86210). I especially wish to thank Nadine Sika for her support in the data collection in Egypt, as well as Maria Josua, Roy Karadag and the anonymous reviewers for their helpful comments on an earlier version of this manuscript.

92 Paul D. Almeida, "Opportunity organizations and threat-induced contention: Protest waves in authoritarian settings," American Journal of Sociology 109/2 (2003): 345-400; Sabine C. Carey, Protest, Repression and Political Regimes.

93 Adam Przeworski, Democracy and the Market.

94 Ellen Lust-Okar, Structuring Conflict in the Arab World, 79.

95 Isabelle Werenfels and Ilyas Saliba, "No Rivals to the King. The Limits to Political Reform in Morocco's 'Enlightened Authoritarianism," swP Comments 17 (May 2017): 1. 